\title{
Embryo Localization Enhances the Survival of Acidovorax citrulli in Watermelon Seeds
}

\author{
Bhabesh Dutta, Raymond W. Schneider, Clark L. Robertson, and Ronald R. Walcott
}

First author: Department of Plant Pathology, Coastal Plain Experiment Station, University of Georgia, Tifton 31793; second and third authors: Department of Plant Pathology and Crop Physiology, Louisiana State University Agricultural Center, Baton Rouge 70803; and fourth author: Department of Plant Pathology, University of Georgia, Athens 30602.

Accepted for publication 6 January 2016.

\begin{abstract}
Dutta, B., Schneider, R. W., Robertson, C. L., and Walcott, R. R. 2016. Embryo localization enhances the survival of Acidovorax citrulli in watermelon seeds. Phytopathology 106:330-338.

Acidovorax citrulli, the causal agent of bacterial fruit blotch (BFB) of cucurbits has been observed to survive for $>34$ years in stored melon and watermelon seeds. To better understand this remarkable longevity, we investigated the bacterium's tolerance to desiccation and the effect of bacterial localization in different watermelon seed tissues on its survival. We compared the ability of $A$. citrulli to tolerate desiccation on filter paper discs and on host (watermelon) and nonhost (cabbage, corn and tomato) seeds to two seedborne (Xanthomonas campestris pv. campestris and Pantoea stewartii subsp. stewartii) and one soilborne (Ralstonia solanacearum) plant-pathogenic bacteria. A. citrulli survival on dry filter paper ( $>12$ weeks) was similar to that of $X$. campestris pv. campestris but longer than $P$. stewartii subsp. stewartii. Ralstonia solanacearum survived longer than all other bacteria tested. On all seeds tested, A. citrulli and $X$. campestris pv. campestris populations declined by 5 orders of magnitude after 12 weeks of incubation at $4^{\circ} \mathrm{C}$ and $50 \%$ relative humidity, while $R$. solanacearum populations declined by 3 orders.

P. stewartii subsp. stewartii was not recovered after 12 weeks of incubation. To determine the effect of tissue localization on bacterial survival, watermelon seeds infested with A. citrulli by flower stigma inoculation (resulting in bacterial localization in the embryo/endosperm) or by ovary pericarp inoculations (resulting in bacterial localization under the testa) were treated with peroxyacetic acid or chlorine $\left(\mathrm{Cl}_{2}\right)$ gas. Following these treatments, a significantly higher reduction in BFB seed-to-seedling transmission was observed for seeds generated by ovary pericarp inoculation $(\geq 89.5 \%)$ than for those generated by stigma inoculation $(\leq 76.5 \%)$ $(P<0.05)$. Additionally, higher populations of $A$. citrulli survived when the bacteria were localized to the embryo/endosperm versus the seed coat, suggesting that tissue localization is important for bacterial survival in seed. This observation was confirmed when $P$. stewartii subsp. stewartii survived significantly longer in stigma-inoculated (embryo/endosperm-localized) watermelon seeds than in vacuum-infiltrated (testa-localized) seeds. Based on these results we conclude that A. citrulli cells are not intrinsically tolerant to desiccation and that localization of the bacterium to testa tissues does not enhance $A$. citrulli survival. In contrast, it is likely that embryo/endosperm localization enhances the survival of $A$. citrulli and other bacteria in seeds.
\end{abstract}

Since the first outbreak in Florida in 1989, bacterial fruit blotch (BFB), caused by Acidovorax citrulli (syn. Acidovorax avenae subsp. citrulli formerly Pseudomonas pseudoalcaligenes subsp. citrulli) (Schaad et al. 1978, 2008; Willems et al. 1992) has become a sporadic but devastating threat to watermelon (Citrullus lanatus [Thunb.] Matsum. \& Nakai) and other cucurbit crops worldwide (Burdman et al. 2005; Latin and Rane 1990; Latin and Hopkins 1995; Schaad et al. 2003; Somodi et al. 1991). A. citrulli is seedborne and seed-to-seedling transmitted in many cucurbitaceous crops (Hopkins and Thompson 2002; Rane and Latin 1992). Infested seeds are the most important source of primary inoculum for BFB epidemics (Hopkins and Thompson 2002; Rane and Latin 1992); however, little is known about the factors that influence A. citrulli survival in seeds. Block and Shepherd (2008) reported that $A$. citrulli survived for more than 34 years on watermelon and melon (Cucumis melo L. var. cantalupensis Naudin) seeds stored at $5^{\circ} \mathrm{C}$ at the USDA North Central Plant Introduction Station, Ames, IA. BFB seed-to-seedling transmission was reported for 2 and $8 \%$ of these melon and watermelon seedlots, respectively (Block and Shepherd 2008), and the authors suggested that the pathogen might survive as long as the seeds remained viable.

In general, the longevity of a seedborne pathogen is influenced by a range of factors including seed storage conditions; intrinsic

Corresponding author: R. R. Walcott; E-mail address: rwalcott@uga.edu characteristics of the pathogen, e.g., tolerance to desiccation; and the location of bacteria in seeds (Schuster and Coyne 1974). Latin et al. (1995) reported that $A$. citrulli survived for only 63 days on the surface of untreated Speedling polystyrene trays (TSC Polyform, Minneapolis, MN) containing potting soil and seedling root debris (Latin et al. 1995). This observation suggests that the bacterium's longevity in stored cucurbit seed might not be due to its intrinsic tolerance to desiccation. One alternative explanation for A. citrulli's extraordinary longevity is its location in cucurbit seeds.

Seed treatments with hydrochloric acid, sodium hypochlorite and peroxyacetic acid are commonly used for BFB management (Hopkins et al. 2003; Walcott 2008); however, they usually do not eradicate the pathogen (Hopkins et al. 2003; Rane and Latin 1992), suggesting that the pathogen can be localized in protected seed tissues under the testa. Dutta et al. (2012) reported that $A$. citrulli localization in watermelon seeds was influenced by the pathway of bacterial invasion (Dutta et al. 2012). More specifically, ingress through the ovary pericarp resulted in the localization of A. citrulli cells just under the testa while ingress through the pistil via stigma inoculation resulted in bacterial localization in the embryo/endosperm (Dutta et al. 2012). Despite these observations, to date there have been no efforts to determine how tissue localization affects $A$. citrulli survival in seeds. Hence, the goal of this study was to investigate the factors that influence $A$. citrulli survival in watermelon seeds. Specific objectives were to (i) compare A. citrulli tolerance to desiccation to other phytopathogenic bacteria; (ii) determine if seed species affects A. citrulli survival; 
and (iii) determine the effect of tissue localization on bacterial survival in watermelon seed.

\section{MATERIALS AND METHODS}

Bacterial strains. The strains of A. citrulli, Xanthomonas campestris pv. campestris, Pantoea stewartii subsp. stewartii, and Ralstonia solanacearum used in this study were AAC00-1 (Walcott and Gitaitis 2000), XCC00-1 (from culture collection of R. Walcott, University of Georgia), DS-203 (provided by D. Coplin, Ohio State University), and AW-1 (Brumbley and Denny 1990), respectively. XCC00-1 (resistant to streptomycin) and DS-203 (resistant to nalidixic acid) were isolated from cabbage and corn, respectively, while AAC00-1 (A. citrulli) and AW-1 ( $R$. solanacearum) were isolated from watermelon and tomato, respectively. A. citrulli AAC00-1 was cultured on King's medium B (King et al. 1956), X. campestris pv. campestris XCC00-1 was grown on yeast dextrose calcium carbonate agar (YDC) (Schaad et al. 2001) amended with $100 \mu \mathrm{g} / \mathrm{ml}$ of streptomycin, P. stewartii subsp. stewartii DS-203 was grown on Luria Bertani (LB) (Schaad et al. 2001) agar amended with nalidixic acid at $50 \mu \mathrm{g} / \mathrm{ml}$, and $R$. solanacearum AW-1 was grown on LB agar. Inoculum for each bacterium was prepared by transferring a single colony from a 24 to $48 \mathrm{~h}$ agar plate culture into nutrient broth followed by overnight incubation at $28^{\circ} \mathrm{C}$ on a rotary shaker (Innova; New Brunswick Scientific Co., Edison, NJ) at $250 \mathrm{rpm}$. Subsequently, cultures were centrifuged at $6,000 \times g$ (Allegra 25R centrifuge, Beckman Coulter, Fullerton, CA) for $5 \mathrm{~min}$ and the supernatant was decanted. The resulting pellets were resuspended in $0.01 \mathrm{M}$ phosphate buffered saline (PBS) and the bacterial concentrations were adjusted to optical densities of $0.3,0.5,0.3$, and 0.1 for $A$. citrulli, P. stewartii subsp. stewartii, $X$. campestris pv. campestris, and $R$. solanacearum, respectively, at $600 \mathrm{~nm}\left(\sim 1 \times 10^{8} \mathrm{CFU} / \mathrm{ml}\right)$ (Spectronic 20; Bausch and Lomb, Rochester, NY).

A. citrulli tolerance to desiccation. Since tolerance to desiccation is an important factor for bacterial survival, we compared the desiccation tolerance of $A$. citrulli to other phytopathogenic bacteria. Bacterial suspensions containing $\sim 1 \times 10^{8} \mathrm{CFU} / \mathrm{ml}$ of A. citrulli AAC00-1, X. campestris pv. campestris XCC00-1, $P$. stewartii subsp. stewartii DS-203 and $R$. solanacearum AW-1 were generated as described above and pieces $\left(\sim 40 \mathrm{~cm}^{2}\right)$ of sterile filter paper (Whatman Inc., Sanford, ME) were incubated in each suspension for $10 \mathrm{~min}$ followed by air drying at $\sim 25^{\circ} \mathrm{C}$ for $12 \mathrm{~h}$. After drying, each piece of filter paper was incubated in a partially open Petri dish in a desiccator cabinet (Secador 4.0, Scienceware, Pequannock, NJ) at $50 \%$ relative humidity $(\mathrm{RH})$. The desired $\mathrm{RH}$ was achieved by placing a 1:1 mixture of terpentine oil (Pine Chemicals Pvt. Ltd., Singapore) and water in the desiccator and incubating at $4^{\circ} \mathrm{C}$. Pieces of filter paper saturated with PBS served as negative controls. After 0 (filter paper processed immediately after inoculation), 1, 2, 3, 4, 8, and 12 weeks postinoculation (WPI), samples of filter paper $\left(\sim 4 \mathrm{~mm}^{2}\right)$ were removed and macerated using a sterile glass rod in a sterile $1.5-\mathrm{ml}$ microcentrifuge tube containing $1 \mathrm{ml}$ of PBS. Macerates were vortexed for $30 \mathrm{~s}$ (Vortex Genie2; Fisher Scientific International, Pittsburgh, PA) and bacterial populations were estimated by 10 -fold serial dilution in PBS followed by spread plating $100 \mu \mathrm{l}$ of aliquots onto respective semiselective agar media as described above. For A. citrulli, the proprietary Nunhem's agar (Nunhems Seed Company, Haelen, Holland) was used as a semiselective medium (Walcott et al. 2003). Bacterial colonies were counted after 24 to $72 \mathrm{~h}$ of incubation. In addition, confirmation of the identity of the bacterial colonies was conducted by PCR assay using $A$. citrulli-, P. stewartii subsp. stewartii-, $X$. campestris pv. campestris-, and $R$. solanacearumspecific primers, as previously described (Chen et al. 2010; Fessehaie et al. 2006; Ha et al. 2009; Park et al. 2004). This experiment was conducted two times and each treatment was replicated three times per experiment. Bacterial populations $\left(\mathrm{CFU} / \mathrm{mm}^{2}\right)$ were $\log _{10}$-transformed prior to analysis. Data were pooled to determine mean bacterial populations after preliminary statistical analysis showed no significant $(P>0.05)$ effect of replication and experiment. Repeated measures analysis of variance was conducted on $\log _{10}$-transformed bacterial population data, where storage time and bacterial species served as repeated measures. The statistical analysis was conducted using the General Linear Model (PROC GLM) in SAS (version 9.2 for Windows; SAS Institute Inc., Cary, $\mathrm{NC)}$ to determine the effect of storage time on mean bacterial population and the differences in the abilities of bacterial species to survive on filter paper at $P<0.05$.

Survival of phytopathogenic bacteria on host and nonhost seed species. It is possible that association with seeds of host and nonhost plants influence bacterial longevity in storage. Hence, we assessed if $A$. citrulli association with host or nonhost seeds affected its survival and how this survival compared with that of other phytopathogenic bacteria. To achieve this, A. citrulli, P. stewartii subsp. stewartii, X. campestris pv. campestris, and $R$. solanacearum strains were inoculated separately onto their respective host and nonhost seeds by vacuum infiltration as described below. Each bacterial strain was inoculated separately onto watermelon ('Crimson Sweet'), corn (Zea mays L. 'Tom Tom'), cabbage (Brassica oleracea L. 'Saratoga'), and tomato (Lycopersicon esculentum L. 'Bonnie Best') seeds, which represented the natural hosts for A. citrulli, P. stewartii subsp. stewartii, X. campestris pv. campestris, and $R$. solanacearum, respectively. Seeds $(n=25 \mathrm{~g})$ were placed in a sterile $250 \mathrm{ml}$ side-arm flask containing $20 \mathrm{ml}$ of each bacterial cell suspension $\left(\sim 1 \times 10^{8} \mathrm{CFU} / \mathrm{ml}\right)$, and the flask was attached to a vacuum line. Cell suspensions were infiltrated into the seeds by applying vacuum to the flask for $1 \mathrm{~h}$. Seeds were subsequently removed from the cell suspensions and air-dried at $\sim 25^{\circ} \mathrm{C}$ for $24 \mathrm{~h}$. Seeds were then stored in open Petri plates at $4^{\circ} \mathrm{C}$ and $50 \%$ RH. At $0,1,2,3,4,8$, and $12 \mathrm{WPI}$, samples ( $n=1 \mathrm{~g}$ of seed) were crushed using a tissue homogenizer (Homex 6, Bioreba, Reinach, Switzerland). Seed macerates were suspended in $10 \mathrm{ml}$ PBS and transferred to $50 \mathrm{ml}$ polypropylene screw cap tubes (Corning Inc., Corning, NY). Macerates were agitated at $100 \mathrm{rpm}$ (Fisher Vortex Genie2; Fisher Scientific International) for $30 \mathrm{~s}$ and centrifuged at $8,000 \times g$ (Allegra 25R) for $5 \mathrm{~min}$. Subsequently, the supernatant was decanted and the pellet was suspended in $1 \mathrm{ml}$ PBS. Ten-fold serial dilutions of the seed macerates were made in PBS and $100 \mu \mathrm{l}$ aliquots were spread onto respective semiselective agar media. After 24 to $72 \mathrm{~h}$ of incubation at $28^{\circ} \mathrm{C}$, bacterial colonies were counted. For each treatment, three seed samples were tested per time point and the experiment was conducted two times. Bacterial populations $(\mathrm{CFU} / \mathrm{g})$ were $\log _{10}$-transformed prior to analysis. Student's $t$ test was used to compare treatments at $P<0.05$. Data from the replicates of the two experiments were pooled to determine mean bacterial populations after preliminary analysis showed no significant $(P>0.05)$ effect of replication and experiment. Repeated measures analysis of variance was used to determine the effect of host and nonhost seeds on bacterial survival at $P<0.05$, where storage time, seed type and bacterial species served as repeated measures.

Effect of watermelon seed tissue localization on $\mathrm{A}$. citrulli survival. To determine how localization in seed tissues affects A. citrulli longevity watermelon seedlots were inoculated with A. citrulli strain AAC00-1 by flower stigma and ovary pericarp inoculation, as described previously (Dutta et al. 2012; Lessl et al. 2007; Walcott et al. 2003). Four A. citrulli-infested seedlots (two each by stigma and ovary pericarp inoculation) were generated (Table 1). Pericarp-inoculated seedlots (1 and 2) were generated in 2009 and 2010, respectively, as follows. Twenty-five watermelon plants (Crimson Sweet) were grown in pots under greenhouse conditions at approximately $24^{\circ} \mathrm{C}$ and $65 \% \mathrm{RH}$ with 12 to $14 \mathrm{~h}$ of natural sunlight daily. At anthesis, 30 to 40 attached female flowers were hand-pollinated and the pericarps of the ovaries were uniformly inoculated by gently rubbing them with cotton-tipped applicators 
saturated with $A$. citrulli AAC00-1 cell suspension $\left(1 \times 10^{6}\right.$ A. citrulli $\mathrm{CFU} / \mathrm{ml}$ ). Inoculated ovaries were covered with plastic bags and incubated for $24 \mathrm{~h}$. After incubation, bags were removed and ovaries were allowed to develop for 30 days. Fruits $(n=20)$ were then harvested and stored at $4^{\circ} \mathrm{C}$ until seed extraction. Seeds were manually extracted from each fruit, air-dried overnight at $25^{\circ} \mathrm{C}$ on paper towels, and pooled before storing in paper bags at $4^{\circ} \mathrm{C}$.

Seedlots with infested embryo/endosperm tissues were generated by pollinating female watermelon flowers at anthesis and inoculating their stigmas with AAC00-1 (Dutta et al. 2012; Walcott et al. 2003). Stigma-inoculated seedlots ( 3 and 4 ) were generated under greenhouse conditions in 2009 and 2010, respectively. Briefly, 25 watermelon plants (Crimson Sweet) were established in pots under greenhouse conditions as described above and at anthesis female blossoms were pollinated manually followed immediately by the inoculation of the stigmas with $10 \mu \mathrm{l}$ of a bacterial suspension containing $\sim 1 \times 10^{8}$ AAC00-1 CFU/ml $\left(\sim 1 \times 10^{6}\right.$ CFU/flower). Inoculum was applied to the stigmas with a micropipette. At least five flowers were inoculated and tagged per plant, which were later thinned to one fruit per pot. Fruits were allowed to develop for 30 days after pollination, at which time, they were harvested and seeds from individual fruit were extracted and air-dried. Seeds from each fruit were combined and stored at $4{ }^{\circ} \mathrm{C}$ until they were used. Seeds harvested from fruits $(n=20$ fruits/inoculation type) that developed from flowers treated with PBS by each inoculation method served as negative controls.

Seedlot characteristics. To determine the percentage of A. citrulli-infested seeds in each lot, four samples ( $n=100$ seeds/lot) were planted in transparent plastic boxes $(6 \mathrm{~cm}[\mathrm{H}] \times 24 \mathrm{~cm}[\mathrm{~W}] \times$ $33.5 \mathrm{~cm}$ [L]; Tri-State Plastics, Dixon, KY) on blotter paper (Anchor Paper Co., St. Paul, MN) saturated with sterile water and maintained at $28^{\circ} \mathrm{C}$ and $85 \% \mathrm{RH}$ for 14 days. Seeds from fruits that developed after stigma- and pericarp-inoculation with PBS served as negative controls. Seed germination and BFB seed-to-seedling transmission percentages (number of seedlings with symptoms divided by the total number of seeds germinated $\times 100$ ) were determined 14 days after planting (DAP). Additionally, mean A. citrulli $\mathrm{CFU} / \mathrm{seed}$ were determined for samples ( $n=30$ seeds) from each lot by 10 -fold serial dilution of individually macerated seeds followed by spread-plating onto Nunhem's semiselective agar. Bacterial colonies were counted after incubating agar plates for $72 \mathrm{~h}$ at $28^{\circ} \mathrm{C}$ and mean CFU/seed was estimated for each lot.

Confirmation of the location of $A$. citrulli in seed tissues after stigma and pericarp inoculation. The location of $A$. citrulli cells in pericarp- and stigma-inoculated watermelon seed samples was confirmed as previously described (Dutta et al. 2012). Fifty seeds from each lot were individually dissected into sections including testa, perisperm-endosperm (PE) layer, and embryo. Testa, PE layer, and embryo sections dissected from 50 seeds each from fruit whose stigmas and pericarps were treated with PBS served as negative controls. Each seed section was macerated separately with a sterilized glass rod in a microcentrifuge tube containing $1 \mathrm{ml}$ of PBS. One hundred microliter aliquots of tissue macerate were spread onto Nunhems medium in triplicate and incubated for $72 \mathrm{~h}$ at $28^{\circ} \mathrm{C}$. Plates were visually inspected for colonies with typical A. citrulli morphology to determine if tissue sections were infested. This experiment was conducted two times and the mean percentage of $A$. citrulli-positive seed sections was determined.

Effect of watermelon seed tissue localization on the efficacy of seed treatments against $\boldsymbol{A}$. citrulli. Because a multiyear pathogen survival study with naturally infested seeds was impractical, we used liquid and gaseous antimicrobial seed treatments to determine the effect of seed tissue localization on A. citrulli response to stress. We hypothesized that $A$. citrulli in stigma-inoculated seeds would survive externally applied liquid seed treatments better than in pericarp-inoculated seeds. We also hypothesized that gaseous chlorine treatments that penetrated watermelon seed tissues would have a greater negative effect on $A$. citrulli survival in stigma-inoculated seeds than externally applied antimicrobial compounds.

Watermelon seeds generated by pericarp and stigma inoculation were treated with peroxyacetic acid (Tsunami 100, Ecolab, McDonough, GA) or chlorine $\left(\mathrm{Cl}_{2}\right)$ gas. For treatment with peroxyacetic acid, seeds $[n=20 \mathrm{~g} / \mathrm{lot}(\sim 450$ seeds $)]$ were placed in a $250 \mathrm{ml}$ side-arm flask with $100 \mathrm{ml}$ of peroxyacetic acid $(1,600 \mu \mathrm{g} / \mathrm{ml})$. The flask was sealed with a rubber stopper and a vacuum was drawn for $20 \mathrm{~min}$. The peroxyacetic acid was decanted; and seeds were rinsed with sterile water for $10 \mathrm{~min}$ followed by drying for $48 \mathrm{~h}$ at $40^{\circ} \mathrm{C}$ in a seed dryer (Grainman Machinery Manufacturing Corp., Miami, FL). Pericarp- and stigma-inoculated seeds $(n=20 \mathrm{~g})$ vacuum-infiltrated with PBS served as positive controls. Seeds ( $n=20 \mathrm{~g}$ ) from PBS-treated flowers (stigma and pericarp inoculation) that were vacuum-infiltrated with peroxyacetic acid served as a negative controls.

For chlorine gas treatment, seeds $(n=20 \mathrm{~g} / \mathrm{lot})$ were placed in a glass chamber $(50 \mathrm{~cm} \times 25 \mathrm{~cm} \times 30 \mathrm{~cm})$ fitted with plastic support racks, a 400-ml mixing vat, a $\mathrm{pH}$ probe, wet and dry bulb thermometers, a propeller for mixing the atmosphere, and a glass top with sample septa. The propeller was attached to a stainless steel shaft that protruded through an impervious gland in the glass top. The shaft was attached to a variable speed electric motor, which was operated at $\sim 200 \mathrm{rpm}$. Chlorine gas was generated by mixing $100 \mathrm{ml}$ of a freshly made solution of $6.0 \% \mathrm{NaOCl}$ and $100 \mathrm{ml}$ of $0.6 \mathrm{M}$ monobasic potassium phosphate buffer in the mixing vat via a funnel and tube that passed through a sealed port in the glass top as described previously (Stephens et al. 2008). Chlorine concentrations inside the chamber were monitored with a Kitagawa gas detector system (Matheson Trigas, Newark, CA). Seeds were placed in open glass Petri dishes that were fully exposed to the atmosphere inside the glass chamber for $9 \mathrm{~h}$. The concentration of chlorine gas inside the airtight chamber was maintained at a range of 400 to $500 \mathrm{ppm}$. Seeds from PBS-treated flowers (pericarp and stigma) exposed to chlorine gas served as negative controls. Untreated pericarp- and stigma-inoculated seeds from corresponding lots were used as positive controls.

TABLE 1. Characteristics of watermelon seedlots generated for this study

\begin{tabular}{lcccc}
\hline Seedlot & Inoculation method & $\begin{array}{c}\text { Mean Acidovorax citrulli } \\
\text { population per seed (CFU) }\end{array}$ & Mean seed germination $(\%)^{\mathrm{b}}$ & Mean BFB seedling transmission $(\%)^{\mathrm{c}}$ \\
\hline 1 & Pericarp & $3.8 \times 10^{4}\left(1.2 \times 10^{2}\right)^{\mathrm{d}}$ & $77.5(2.67)$ & $61.3(1.42)$ \\
2 & Pericarp & $2.1 \times 10^{4}\left(3.4 \times 10^{2}\right)$ & $68.0(1.34)$ & $64.7(2.54)$ \\
3 & Stigma & $4.7 \times 10^{4}\left(3.7 \times 10^{2}\right)$ & $74.0(3.26)$ & $56.8(3.87)$ \\
4 & Stigma & $6.5 \times 10^{4}\left(3.4 \times 10^{3}\right)$ & $85.0(1.84)$ & $63.5(2.17)$ \\
\hline
\end{tabular}

a Mean A. citrulli population per seed recovered by crushing individual seeds ( $n=30$ seeds/lot) in 0.1 M phosphate-buffered saline followed by dilution plating on Nunhem's semiselective medium.

b Mean seed germination percentages for four replicates of seed samples $(n=100 /$ replicate) from each lot. Seeds were planted in transparent, closed, plastic boxes with saturated blotter paper and incubated for 14 days at $28^{\circ} \mathrm{C}$ and $80 \%$ relative humidity.

${ }^{c}$ Mean bacterial fruit blotch (BFB) seedling transmission percentages for four replicates of seed samples ( $n=100 /$ replicate) from each lot. Seeds were planted in transparent, closed, plastic boxes with saturated blotter paper and incubated for 14 days at $28^{\circ} \mathrm{C}$ and $80 \%$ relative humidity. BFB seedling transmission percentages were recorded as number of seedlings showing typical BFB symptoms divided by total number of seeds germinated $\times 100$.

$\mathrm{d}$ Numbers in parentheses denote standard error of the mean. 
For the two treatments $\left(\mathrm{Cl}_{2}\right.$ versus peroxyacetic acid), three replicates of seeds from each seedlot of each inoculation type (pericarp or stigma) were used in a single experiment and the experiment was conducted twice. To determine the effect of the seed treatments on A. citrulli survival, the percent reduction in BFB seedto-seedling transmission ([BFB transmission percentage for the positive control lot $-\mathrm{BFB}$ transmission percentage for the treated lot]/BFB transmission percentage for the positive control lot $\times 100$ ) and percent reduction in infested seeds ([percentage of infested seeds for the positive control lot - percentage of infested seeds after seed treatment]/percentage of seeds for the positive control lot $\times 100$ ) was determined for each seed sample. Mean reductions of BFB seed-to-seedling transmission percentage and percentage of infested seeds were calculated for seed samples from individual lots.

To determine the effect of peroxyacetic acid and $\mathrm{Cl}_{2}$ gas seed treatments on BFB seed-to-seedling transmission, samples $(n=100$ seeds/replicate/lot) were planted in transparent plastic boxes on blotter paper and maintained at $28^{\circ} \mathrm{C}$ and $\sim 85 \% \mathrm{RH}$ as described above. Seed germination and BFB seed-to-seedling transmission percentages were recorded at 14 DAP. Seed samples from positive and negative control lots were also tested and percent reduction in BFB seed-to-seedling transmission was determined. To estimate the percentage of $A$. citrulli infested seeds, samples ( $n=20$ seeds/replicate/lot) from each treatment were crushed individually in $1 \mathrm{ml}$ of PBS and $100 \mu \mathrm{l}$ aliquots were spread onto Nunhem's agar plates. After $72 \mathrm{~h}$ of incubation, plates were visually examined for the presence of $A$. citrulli colonies and the percentage of $A$. citrulli infested seeds was recorded. A seed was considered positive when at least one $A$. citrulli colony was detected on the agar plate. The percent reduction in infested seeds was calculated as described above. The significance of the effect of seed treatment on reduction of BFB seed-to-seedling transmission and A. citrulli-infested seeds was determined by analysis of variance (ANOVA) using PROC GLM of SAS. Means separation was conducted using least significant difference (LSD) $(P<0.05)$.

Effect of watermelon seed localization on $P$. stewartii subsp. stewartii survival. The effect of seed tissue localization on bacterial survival was further explored using watermelon seeds internally infested with $P$. stewartii subsp. stewartii by stigma inoculation. P. stewartii subsp. stewartii is a seedborne pathogen of maize, but it does not survive for long periods on corn seed (Michener et al. 2002). We hypothesized that when localized in the embryo/endosperm of watermelon seeds, $P$. stewartii subsp. stewartii would survive longer than on the surface or just under the testa. Using our knowledge of the pathways of seed infection by A. citrulli, we localized $P$. stewartii subsp. stewartii cells in the embryo/endosperm of watermelon seed. We then compared the ability of P. stewartii subsp. stewartii to survive in the watermelon seed endosperm/ embryo to its ability to survive just under the testa. Two watermelon seedlots infested with $P$. stewartii subsp. stewartii DS203 were generated in May and September of 2010, respectively by stigma inoculation as described above. Twenty-five and thirty fruits were harvested from the greenhouse experiments in May and September (2010), respectively. Seeds from fruits $(n=20)$ whose stigmas were treated with PBS served as negative controls.

To confirm that stigma inoculation deposited $P$. stewartii subsp. stewartii cells in the embryos of watermelon seeds, seed samples ( $n=50$ seeds/lot) were dissected into seed coat (testa), perispermendosperm (PE) layer, and embryo tissues as described previously (Dutta et al. 2012). Similar tissues were dissected from 10 seeds from fruit whose stigmas were treated with PBS as negative controls. Each seed tissue type was crushed in a separate microcentrifuge tube and total microbial genomic DNA was extracted using an UltraClean Microbial DNA Kit (MO BIO, Carlsbad, CA) according to the manufacturer's instructions. DNA was used to test for $P$. stewartii subsp. stewartii by species-specific, real-time PCR assay and plating on LB agar amended with nalidixic acid at $50 \mu \mathrm{g} / \mathrm{ml}$. For real-time PCR, $25 \mu \mathrm{M}$ each of primer (ES-F (TGCGAAGCGAGGACACACGTA) and ES-R (GACACCTTTCACCTGTCACCAA) [Fessehaie et al. 2006]) was used with approximately $5 \mathrm{ng} / \mu \mathrm{l}$ of DNA per sample. DNA amplification was conducted using a SYBR green mastermix (SoFast EvaGreen Supermix, Bio-Rad Laboratories Inc., Hercules, CA) and a Smart Cycler PCR machine (Cepheid, Sunnyvale, CA). The following thermal profile was used: denaturation at $95^{\circ} \mathrm{C}$ for $180 \mathrm{~s}$, followed by 35 cycles of denaturation at $95^{\circ} \mathrm{C}$ for $15 \mathrm{~s}$, and annealing and elongation at $55^{\circ} \mathrm{C}$ for $40 \mathrm{~s}$. Samples with cycle threshold $(\mathrm{Ct})$ values below 35 were considered to be positive for P. stewartii subsp. stewartii. Additionally, seed sections from 50 seeds per stigma-inoculated lot were crushed individually in $1 \mathrm{ml}$ of PBS, and $100 \mu \mathrm{l}$ of tissue extract was spread onto LB agar plates amended with nalidixic acid at $50 \mu \mathrm{g} / \mathrm{ml}$. Plates were incubated for $48 \mathrm{~h}$ at $28^{\circ} \mathrm{C}$ and visually examined for $P$. stewartii subsp. stewartii colonies. This experiment was conducted two times and the mean percentages of $P$. stewartii-positive seed sections were determined by PCR and agar plating assays. For statistical analysis the mean percentages of $P$. stewartii subsp. stewartii-positive seed sections (for both PCR and plating results) were compared by ANOVA using PROC GLM $(P<0.05)$ and mean separation was conducted by Fisher's LSD test.

For inoculation by vacuum-infiltration, two watermelon (Crimson Sweet) seed samples ( $30 \mathrm{~g}$ of seeds each) were placed in a suspension containing $\sim 1 \times 10^{6}$ P. stewartii subsp. stewartii $\mathrm{CFU} / \mathrm{ml}$ and processed as described above. Seeds were subsequently air-dried for $24 \mathrm{~h}$ in a laminar air-flow chamber. Seedlots vacuum-infiltrated with PBS served as negative controls. After air drying, seedlots were stored in paper for $48 \mathrm{~h}$ at $4^{\circ} \mathrm{C}$.

Watermelon seedlots infested/infected with $P$. stewartii subsp. stewartii were stored at $4^{\circ} \mathrm{C}$ and $50 \% \mathrm{RH}$ for 5 weeks. Seed samples ( $n=1 \mathrm{~g}$ of seed/method of inoculation/sampling time) were removed at $0,1,2$, and 3 WPI, crushed in PBS and 10-fold serially diluted. One-hundred microliter aliquots of seed extract were spread onto LB agar amended with $50 \mu \mathrm{g} / \mathrm{ml}$ at nalidixic acid and bacterial colonies were counted after $48 \mathrm{~h}$ incubation at $28^{\circ} \mathrm{C}$. This experiment was conducted twice and included three replicates per lot/inoculation method/sampling time. Bacterial populations (CFU/g) were $\log _{10^{-}}$ transformed and pooled data from the two experiments were used for statistical analysis after ascertaining lack of significance of the effects of replication and experiment at $P<0.05$. ANOVA using PROC GLM was used to determine the effect of bacterial location in seed tissue on $P$. stewartii subsp. stewartii survival at $P<0.05$, where bacterial location and storage time served as repeated measures.

\section{RESULTS}

A. citrulli tolerance to desiccation. The survival of bacteria on filter paper (at $4^{\circ} \mathrm{C}$ and $50 \% \mathrm{RH}$ ) was significantly affected by storage time and bacterial species $(P<0.001)$. There was a significant difference in desiccation tolerance of different bacterial species on filter paper at $(P=0.01)$. In addition, the interaction between storage time and type of bacterial species was significant $(P=0.022)$. At 0 WPI mean populations of $A$. citrulli, $R$. solanacearum, $X$. campestris pv. campestris, and $P$. stewartii subsp. stewartii on filter paper ranged from $\sim 10^{7}$ to $10^{8} \mathrm{CFU} / \mathrm{mm}^{2}$ (Fig. 1). By 2 WPI the mean $P$. stewartii subsp. stewartii population declined significantly to $1.02 \times 10^{4} \mathrm{CFU} / \mathrm{mm}^{2}(P \leq 0.01)$, while populations of the other bacteria ranged from $2.13 \times 10^{6}$ to $3.63 \times 10^{6} \mathrm{CFU} / \mathrm{mm}^{2}$ (Fig. 1), which were not significantly different to each other $(P \geq 0.79)$. At 4 WPI the mean $P$. stewartii subsp. stewartii population declined to $1.54 \times 10^{3} \mathrm{CFU} / \mathrm{mm}^{2}$, and by $8 \mathrm{WPI}$ it was $1.34 \times 10^{2} \mathrm{CFU} / \mathrm{mm}^{2}$ (Fig. 1). The population levels of $P$. stewartii subsp. stewartii at 4 and 8 WPI were significantly lower than that for other bacteria $(P \leq$ 0.002). P. stewartii subsp. stewartii colonies were not recovered from the filter paper by 12 WPI. In contrast, by 4 WPI mean populations of $X$. campestris pv. campestris, A. citrulli, and $R$. solanacearum declined to a range of $9.33 \times 10^{4}$ to $9.54 \times 10^{5} \mathrm{CFU} / \mathrm{mm}^{2}$, and by 
8 WPI mean populations of $X$. campestris pv. campestris and A. citrulli declined to $2.95 \times 10^{4}$ to $3.23 \times 10^{4} \mathrm{CFU} / \mathrm{mm}^{2}$, while the mean $R$. solanacearum population was $2.15 \times 10^{5} \mathrm{CFU} / \mathrm{mm}^{2}$ (Fig. 1). The populations of $X$. campestris pv. campestris, A. citrulli, and $R$. solanacearum at 4 and 8 WPI were not significantly different $(P \geq 0.96)$. At 12 WPI mean $X$. campestris pv. campestris and A. citrulli populations declined significantly to $2.29 \times 10^{2}$ to $3.09 \times$ $10^{2} \mathrm{CFU} / \mathrm{mm}^{2}$, while $R$. solanacearum populations remained at $1.12 \times 10^{5} \mathrm{CFU} / \mathrm{mm}^{2}$ (Fig. 1) $(P<0.01)$. As expected, bacteria were not recovered from filter paper strips that were inoculated with sterilized PBS.

Survival of phytopathogenic bacteria on host and nonhost seeds. The ability of phytobacteria to tolerate desiccation on host and nonhost seed species after 12 weeks varied significantly $(P<$ 0.01 ) (Fig. 2). While the interaction between storage time and bacterial species was significant $(P<0.01)$, significant interaction between storage time and seed types on bacterial survival was not observed $(P \geq 0.64)$. On watermelon seed, by 12 WPI the mean population of $R$. solanacearum $\left(3.63 \times 10^{4} \mathrm{CFU} / \mathrm{g}\right.$ of seed) was significantly higher than other bacteria $(P<0.01)$ (Fig. 2A). During the same period, no significant differences were observed in the populations of $A$. citrulli $\left(1.65 \times 10^{3} \mathrm{CFU} / \mathrm{g}\right.$ of seed $)$ and $X$. campestris pv. campestris $\left(3.63 \times 10^{2} \mathrm{CFU} / \mathrm{g}\right.$ of seed $)(P=0.26)($ Fig. $2 \mathrm{~A})$. On tomato and corn seed, mean $R$. solanacearum populations at $12 \mathrm{WPI}$ were $1.90 \times 10^{3}$ and $3.32 \times 10^{4} \mathrm{CFU} / \mathrm{g}$, respectively, which were significantly higher than other bacterial species $(P=0.008)$ (Fig. 2B and D). On these seeds, there was no significant difference in the A. citrulli and $X$. campestris pv. campestris populations $(P=0.99)$. The mean populations of $A$. citrulli and $X$. campestris pv. campestris on tomato and corn seeds were $1.69 \times 10^{2}, 2.81 \times 10^{2} \mathrm{CFU} / \mathrm{g}$ of seed and $2.95 \times 10^{2}, 2.88 \times 10^{2} \mathrm{CFU} / \mathrm{g}$ of seed, respectively (Fig. 2B and D). At 12 WPI the mean $R$. solanacearum population was significantly higher on cabbage seeds $\left(\sim 1.31 \times 10^{5} \mathrm{CFU} / \mathrm{g}\right)$ than on other seed types (Fig. 2C). During the same period, A. citrulli and $X$. campestris pv. campestris populations were significantly higher on cabbage seeds than on other seed species, with mean

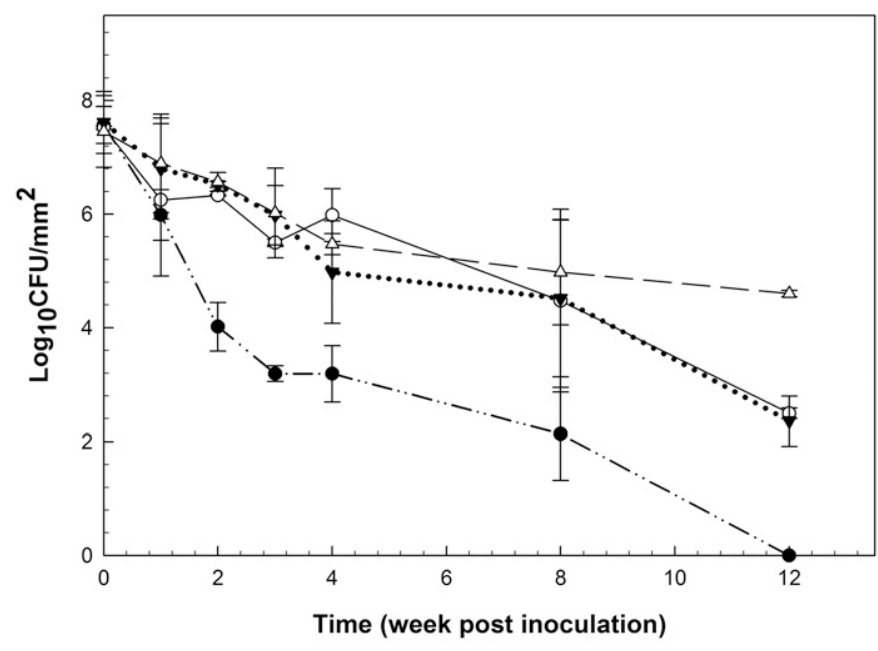

\begin{tabular}{ll}
$-\cdots \rightarrow-\cdots$ & P. stewartii subsp. stewartii \\
\hdashline$-\cdots$ & A. citrulli \\
$\cdots \cdots \cdots \cdots$ & X. campestris pv. camprestris \\
$-\triangle-\cdots$ & R. solanacearum
\end{tabular}

Fig. 1. Survival of Acidovorax citrulli, Pantoea stewartii subsp. stewartii, Xanthomonas campestris pv. campestris, and Ralstonia solanacearum on filter paper at $4^{\circ} \mathrm{C}$ and $50 \%$ relative humidity $(\mathrm{RH})$. Filter paper strips were inoculated with $\sim 10^{8} \mathrm{CFU} / \mathrm{ml}$ of each bacterium and incubated at $4^{\circ} \mathrm{C}$ and $50 \%$ RH for 12 weeks. Each data point represents mean colony forming units per square millimeter as estimated by dilution plating on respective semiselective agar plates. Bars represent standard errors of the means $(n=6)$. populations of $3.09 \times 10^{3}$ and $1.90 \times 10^{3} \mathrm{CFU} / \mathrm{g}$ of seed, respectively (Fig. 2C).

Overall, the difference in survival between bacterial species was statistically significant $(P<0.01)$. By 12 WPI significantly higher populations of $R$. solanacearum $\left(\sim 10^{4}\right.$ to $\left.10^{5} \mathrm{CFU} / \mathrm{g}\right)$ were observed on all seed types (Fig. 2) than for all other bacteria tested. During this same period, there was no significant difference between $A$. citrulli and $X$. campestris pv. campestris populations $\left(\sim 10^{2}\right.$ to $\left.10^{3} \mathrm{CFU} / \mathrm{g}\right)(P \leq 0.27)$ (Fig. 2$)$ and viable colonies of $P$. stewartii subsp. stewartii were not recovered from any of the seeds tested (Fig. 2A to D).

Effect of watermelon seed tissue localization on $A$. citrulli survival. The mean germination percentages of the two pericarpinoculated seedlots 1 and 2, were 77.5 and $68.0 \%$, respectively, and the mean BFB seed-to-seedling transmission percentages were 61.3 and $64.7 \%$ (Table 1 ). The mean A. citrulli population per seed for lots 1 and 2 , were $3.8 \times 10^{4}$ and $2.1 \times 10^{4} \mathrm{CFU}$, respectively. The mean seed germination percentages for the two stigma-inoculated seedlots, 3 and 4, were 74.0 and $85.0 \%$, respectively, and they displayed BFB seed-to-seedling transmission percentages of 56.8 and $63.5 \%$, respectively (Table 1 ). The mean $A$. citrulli population per seed for lots 3 and 4 were $4.7 \times 10^{4}$ and $6.5 \times 10^{4} \mathrm{CFU}$, respectively.

Confirmation of the location of $A$. citrulli in watermelon seed tissues after stigma and ovary pericarp inoculation. For seedlots from pericarp-inoculated fruits the mean percentages of $A$. citrulli-infested testa, $P E$ layer, and embryo/endosperm tissues were $5.5,80.5$, and $10 \%$, respectively. In contrast, for stigmainoculated seedlots A. citrulli was detected in $16.5,79$, and $87 \%$ of the testa, PE layer, and embryo tissues, respectively. These data confirm that stigma inoculation deposited A. citrulli cells into the embryo/endosperm of seeds while pericarp inoculation deposited A. citrulli cells into the testa and PE layer. A. citrulli cells were not detected in tissues of seeds from negative control lots.

Effect of watermelon seed tissue localization on the efficacy of seed treatments against $\boldsymbol{A}$. citrulli. Peroxyacetic acid did not affect the germination of the control seeds $(P=0.34)$ and these seeds did not transmit BFB to resulting seedlings (data not shown). Seed treatment with peroxyacetic acid resulted in a statistically significant reduction in BFB seed-to-seedling transmission percentage $(P=0.01)$; however, no significant difference was observed between lots of the same inoculation type $(P=0.43)$. The mean reduction in BFB seed-to-seedling transmission for seeds treated with peroxyacetic acid was significantly higher for pericarp-inoculated seeds (89.5\%) than for stigma-inoculated seeds (61.1\%) (Fig. 3A). Chlorine gas treatment did not affect watermelon seed germination $(P=0.67)$ but significantly reduced BFB seed-to-seedling transmission for both pericarp- and stigma-inoculated seedlots $(P=0.01)$. With chlorine gas, the reduction in BFB seed-to-seedling transmission for pericarp-inoculated seeds was $99.1 \%$ (Fig. 3A), which was significantly higher than for the stigma-inoculated seeds $(76.5 \%)(P=0.05)$ (Fig. 3A).

Overall, peroxyacetic acid significantly reduced the mean percentage of $A$. citrulli-infested seeds $(P=0.01)$. This reduction was significantly greater for seeds from pericarp-inoculated lots $(74.8 \%)$ than for seeds from stigma-inoculated lots $(9.63 \%)(P=$ 0.01) (Fig. 3B). Additionally, the reduction in the percentage of A. citrulli-infested seeds by chlorine gas treatment was significantly greater for seeds from pericarp-inoculated lots $(80.8 \%)$ than for seeds from stigma-inoculated lots $(54.02 \%)(P=0.05)$ (Fig. 3B). A. citrulli colonies were not recovered from negative control seeds treated with peroxyacetic acid or chlorine gas.

Survival of $P$. stewartii subsp. stewartii in watermelon seeds. To further demonstrate that seed tissue localization affected bacterial survival we investigated if $P$. stewartii subsp. stewartii (a xpoor survivor on corn seed) survival could be enhanced by localization in watermelon seed embryo/endosperm. Previous experiments showed that $P$. stewartii subsp. stewartii was sensitive to desiccation. Since $A$. citrulli survived stress better in stigma-inoculated than in 
pericarp-inoculated seeds, we hypothesized that the survival of $P$. stewartii subsp. stewartii would be enhanced by localization in seed embryo/endosperm tissue.

Tissue sections from negative control seedlots were negative for P. stewartii subsp. stewartii by species-specific PCR assay and plating on agar plates. In contrast, for stigma-inoculated seedlots significantly higher mean percentages of embryo/endosperm $(63 \%$ by PCR assay and $58 \%$ by agar plating) and PE layer ( $48 \%$ by PCR and $34 \%$ by plating) tissue samples were positive for $P$. stewartii subsp. stewartii relative to testa ( $8 \%$ by PCR and $2 \%$ by plating) samples $(P<0.01)$. These data confirmed the localization of $P$. stewartii subsp. stewartii in embryo/endosperm tissues with stigma inoculation.
Overall, the difference between $P$. stewartii subsp. stewartii populations in vacuum-infiltrated and stigma-inoculated watermelon seeds was significant $(P<0.01)$. Pantoea stewartii subsp. stewartii colonies were not recovered from seedlots that were treated with PBS by stigma inoculation or vacuum infiltration at any sampling period. In contrast, at $0 \mathrm{WPI}$, the mean $P$. stewartii subsp. stewartii populations recovered from vacuum-infiltrated and stigmainoculated watermelon seeds were $3.46 \times 10^{6}$ and $1.32 \times 10^{3} \mathrm{CFU} / \mathrm{g}$ of seed, respectively (Fig. 4). By 1 and 2 WPI, the mean bacterial populations recovered from stigma-inoculated seeds were $8.4 \times$ $10^{4}$ and $2.3 \times 10^{4} \mathrm{CFU} / \mathrm{g}$ of seed, respectively. In contrast, in the same period, mean $P$. stewartii subsp. stewartii populations declined to $9.4 \times 10^{2}(1 \mathrm{WPI})$ and $4.3 \times 10^{2} \mathrm{CFU} / \mathrm{g}$ of seed $(2 \mathrm{WPI})$ for

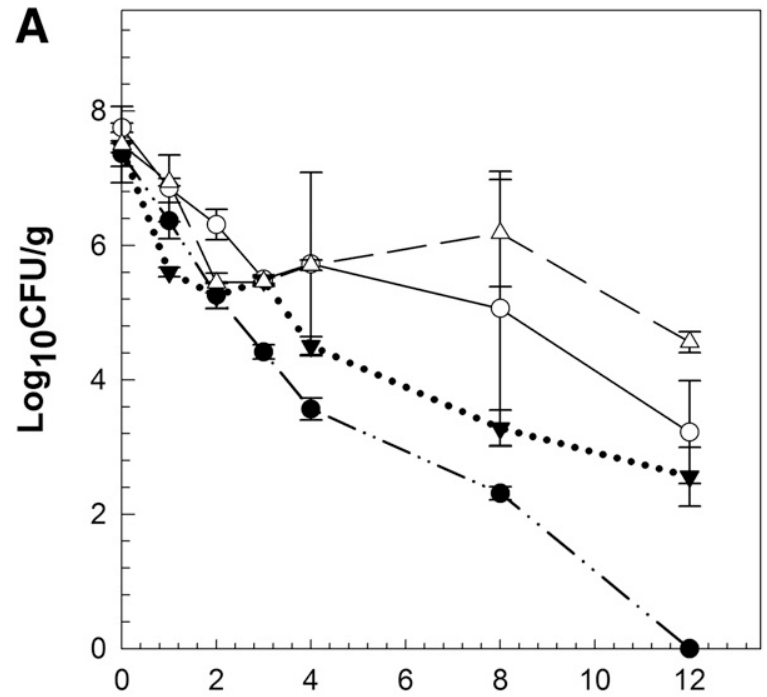

Time (week post inoculation)

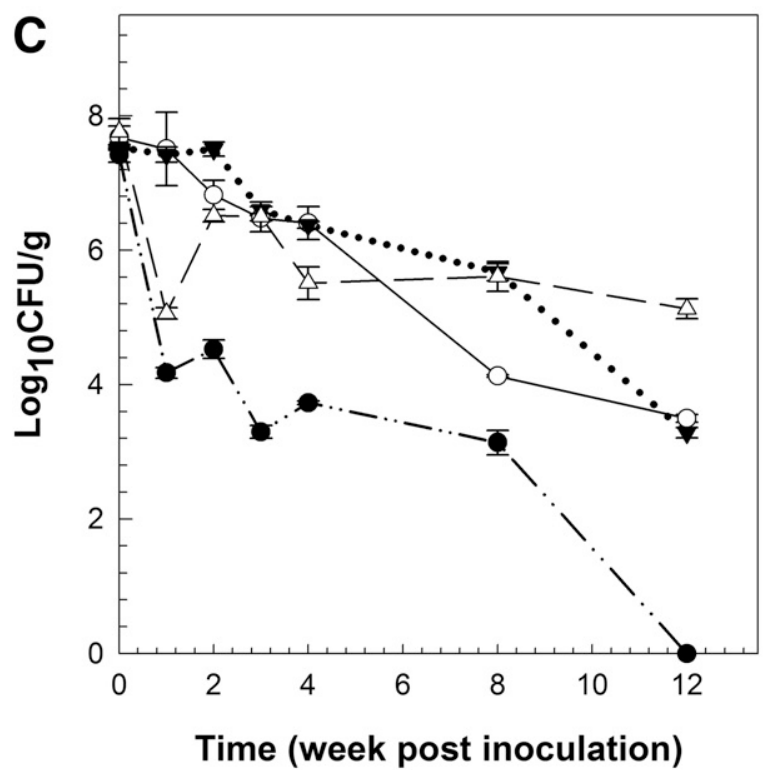

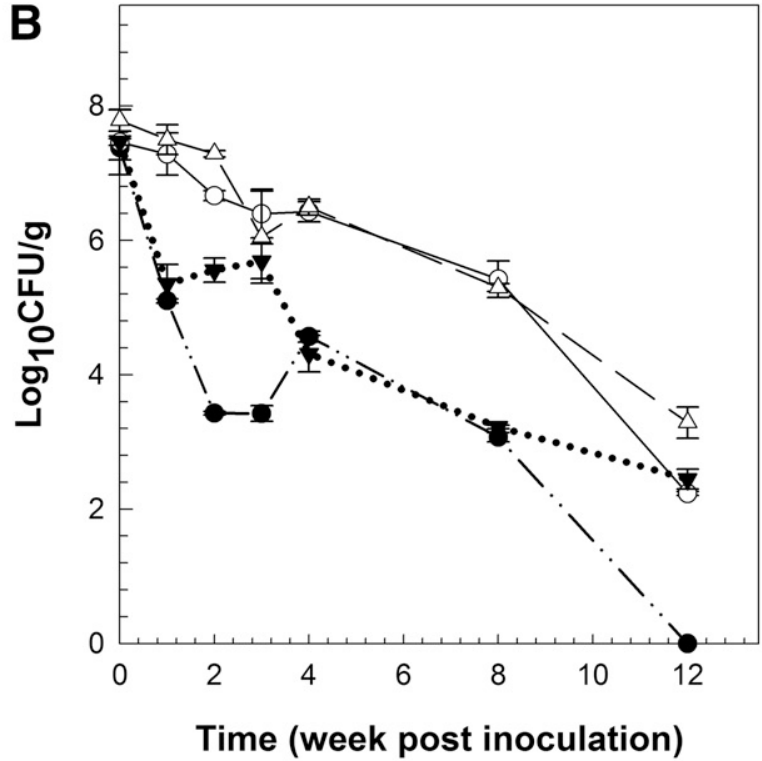

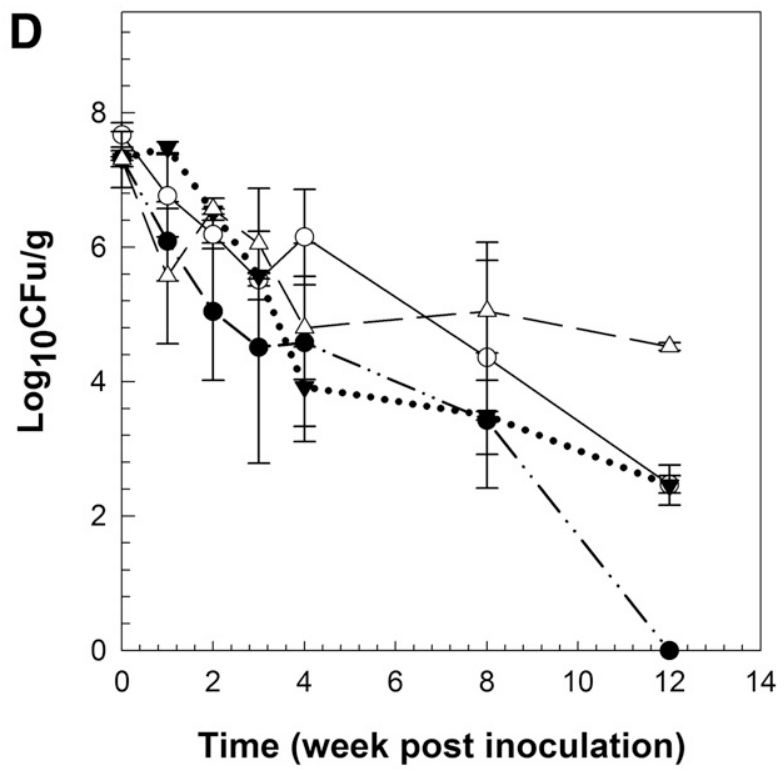

\section{$-\cdots \rightarrow-\cdots \quad P$. stewartii subsp. stewartii

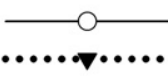 \\ A. citrulli \\ $X$. campestris pv. campestris $R$. solanacearum}

Fig. 2. Survival of Acidovorax citrulli, Pantoea stewartii subsp. stewartii, Xanthomonas campestris pv. campestris, and Ralstonia solanacearum on A, watermelon, $\mathbf{B}$, tomato, $\mathbf{C}$, cabbage, and $\mathbf{D}$, corn seeds. Each seed species was inoculated with $\sim 10^{8} \mathrm{CFU} / \mathrm{g}$ of each bacterium dried to their original weight and incubated at $4{ }^{\circ} \mathrm{C}$ and $50 \%$ relative humidity for 12 weeks. Each data point represents the mean colony forming units per gram of seed estimated by dilution plating of $1 \mathrm{~g}$ of seed at each sample time on respective semiselective agar plates. Bars represent standard errors of the means for three replicates per treatment per experiment and the experiment was conducted twice $(n=6)$. 
vacuum-infiltrated seedlots. By 3 WPI, $P$. stewartii subsp. stewartii colony forming units were not recovered from vacuum-infiltrated seeds, while the mean population recovered from stigma-inoculated seeds was $4.07 \times 10^{3} \mathrm{CFU} / \mathrm{g}$ of seed (Fig. 4).

\section{DISCUSSION}

A range of factors including storage conditions, e.g., temperature, relative humidity, sensitivity to desiccation, and location in seed tissues contribute to phytobacterial survival in seeds (Agarwal and Sinclair 1997; Leben 1981; Schuster and Coyne 1974). Low temperature $\left(5\right.$ to $\left.10^{\circ} \mathrm{C}\right)$ and low moisture $(40$ to $60 \% \mathrm{RH})$ storage conditions extend the viability of seedborne bacteria (Agarwal and Sinclair 1997; Schuster and Coyne 1974). For example, Pseudomonas syringae pv. phaseolicola (causal agent of halo blight of bean) and X. campestris pv. manihotis (causal agent of bacterial blight of cassava) survived longer in bean and cassava seeds, respectively, when stored at 5 to $7^{\circ} \mathrm{C}$ and 50 to $60 \% \mathrm{RH}$ than at 10 to $27^{\circ} \mathrm{C}$ and $<50 \% \mathrm{RH}$ (Persley 1979; Taylor et al. 1979). A. citrulli was reported to survive for 34 to 40 years in watermelon and melon seeds, respectively, stored at $5^{\circ} \mathrm{C}$ and $50 \%$ RH (Block and Shepherd 2008). More recently, A. citrulli was recovered from citron melon (Citrullus lanatus var. citroides, a cucurbitaceous weed prevalent in southeastern United States) seeds that were stored for 7 years at $4^{\circ} \mathrm{C}$ and $50 \% \mathrm{RH}$ (Dutta et al. 2014). Despite these reports of extraordinarily prolonged survival in cucurbitaceous seeds, the factors that influence longevity of $A$. citrulli have not been previously studied. The current study revealed that $A$. citrulli cells are not intrinsically tolerant to desiccation as bacterial CFUs declined rapidly on filter paper stored at $4{ }^{\circ} \mathrm{C}$ and $50 \% \mathrm{RH}$. Even superficial inoculation of A. citrulli onto watermelon seeds did not enhance its survival relative to other phytobacterial species.

We observed that $P$. stewartii subsp. stewartii survived for the shortest time on filter paper, and host and nonhost seeds, suggesting high desiccation sensitivity. This may in part explain the bacterium's poor ability to survive in/on corn seeds (Block et al. 1998; Michener et al. 2002). It may also explain why the corn flea beetle rather than seedborne inoculum is more important in the epidemiology of Stewart's wilt (Block et al. 1998; Block et al. 1999; Michener et al. 2002). In comparison, $R$. solanacearum survived longer than other tested bacteria. This was expected as $R$. solanacearum is a persistent, soil borne bacterium and is likely to be tolerant to environmental stress (Alvarez et al. 2008; Milling et al. 2009). The decline in population over 12 weeks of storage for $A$. citrulli and $X$. campestris pv. campestris were not significantly different $(P>0.05)$ on filter paper or seed tissue. Hence, it is unlikely that the ability of $A$. citrulli to survive for more than 34 years in watermelon and melon seeds is due to its inherent tolerance to desiccation or its superficial association with watermelon seeds.

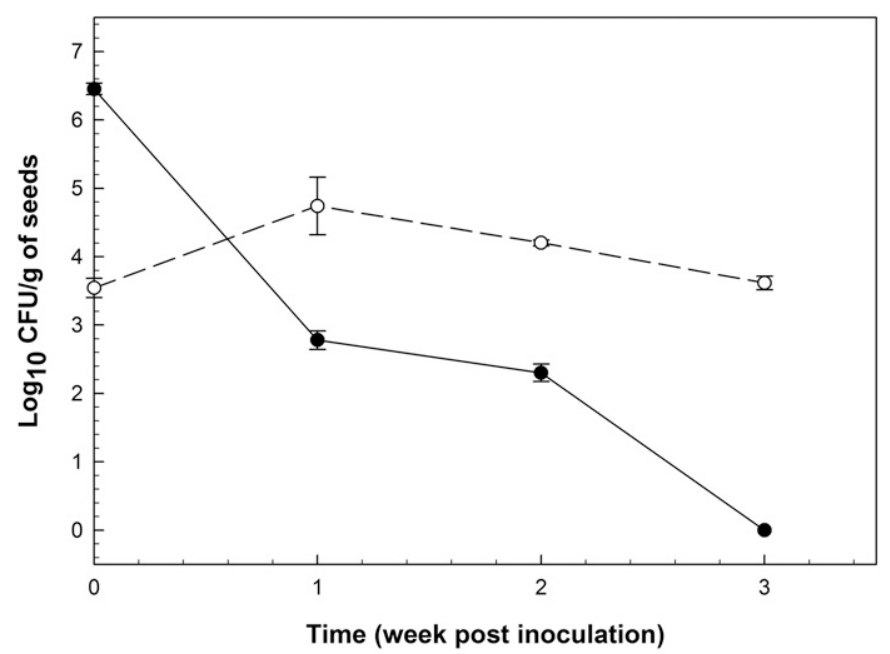

$\longrightarrow \quad P$. stewartii subsp. stewartii (vacuum-infiltrated)

- - - P. stewartii subsp. stewartii (stigma-inoculated)

Fig. 4. Survival of Pantoea stewartii subsp. stewartii in vacuum and stigmainoculated watermelon seeds over time. Vacuum-infiltrated seeds were inoculated with $10^{6} \mathrm{CFU} / \mathrm{ml}$ of Pantoea stewartii subsp. stewartii and air-dried. Internally infested seeds were extracted from fruits whose stigmas were inoculated with bacterial suspension of $\sim 10^{6} \mathrm{CFU} /$ stigma. Seed samples $(30 \mathrm{~g}$ ) from vacuum- and stigma-inoculated lots were incubated at $4{ }^{\circ} \mathrm{C}$ and $50 \%$ relative humidity. Each data point represents mean $\log _{10} \mathrm{CFU} / \mathrm{g}$ of seed estimated by 10 -fold serial dilution plating of $1 \mathrm{~g}$ of seed at each time point on semiselective agar plates. Bars represent standard errors of the means for three replicates and the experiment was repeated twice $(n=6)$.
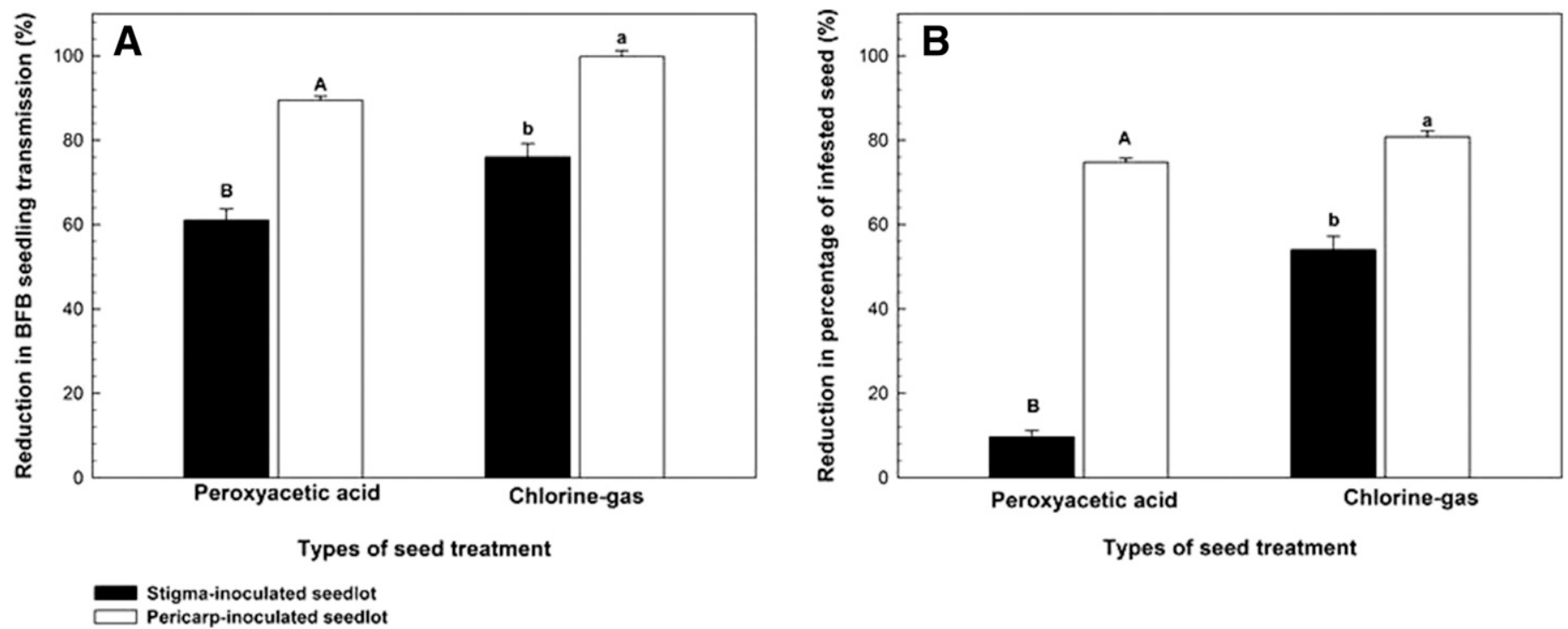

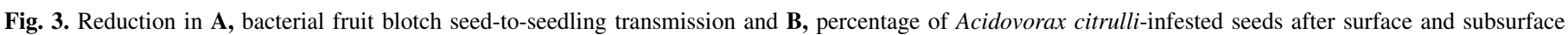

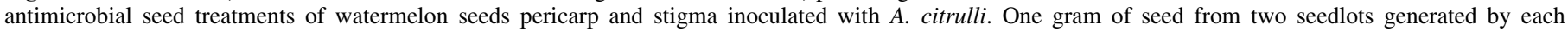

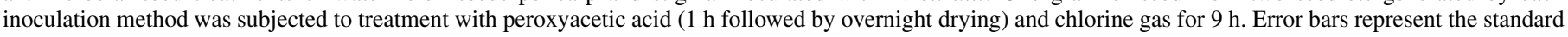

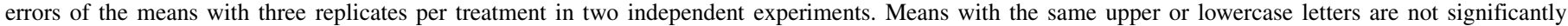
different according to Student's $t$ test $(P=0.05)(n=12)$. 
Since $A$. citrulli can become localized to different watermelon seed tissues depending on the pathway of invasion (Dutta et al. 2012), we hypothesized that seed tissue localization influences bacterial survival. Because of the practical limitations of conducting a multiyear survival study with naturally infested seeds, we used surface and subsurface antimicrobial treatments to determine the effect of tissue localization on bacterial survival. As seed treatments, we employed peroxyacetic acid, an industry standard that is effective on surface and subsurface A. citrulli populations (Hopkins et al. 2003) and chlorine gas, which can theoretically penetrate internal seed tissues (Stephens et al. 2008). However, the depth of seed tissue penetration by gaseous chlorine is unknown. As expected, pericarp and stigma inoculation of watermelon flowers resulted in A. citrulli localization mainly on the surface of the PE layer and in the embryo tissue, respectively (Dutta et al. 2012). Additionally, the levels of $A$. citrulli infestation in pericarp- and stigma-inoculated seedlots were similar based on BFB seedling transmission percentages and mean bacterial populations. Seed treatment with peroxyacetic acid and gaseous chlorine resulted in a significantly greater reduction in the percentage of $A$. citrulli-infested seeds and BFB seed-to-seedling transmission for pericarp-inoculated seedlots than for stigma-inoculated seedlots. Based on this observation, we conclude that $A$. citrulli cells in the embryo of watermelon seeds (stigma-inoculated seeds) are better protected from stress than cells localized under the testa (pericarp-inoculated seeds). Similar effects of bacterial localization on A. citrulli survival were observed for citron melon seed (Dutta et al. 2014). More specifically, A. citrulli survived longer in citron melon seeds generated by stigma inoculation than in seeds generated by pericarp inoculation when stored at $4^{\circ} \mathrm{C}$ and $50 \%$ RH for 7 years (Dutta et al. 2014).

To further confirm that seed tissue localization is an important factor in phytobacterial survival, $P$. stewartii subsp. stewartii was localized to watermelon seed embryo/endosperm tissue by stigma inoculation and its ability to survive was compared with that of watermelon seeds inoculated by vacuum infiltration. Our results showed that watermelon stigma inoculation with P. stewartii subsp. stewartii resulted in localization of the bacterium in the seed embryo. Additionally, while $P$. stewartii subsp. stewartii was not recovered from vacuum-infiltrated watermelon seeds after 3 weeks of storage, $4.07 \times 10^{3} \mathrm{CFU} / \mathrm{g}$ of seed of the pathogen was recovered from stigma-inoculated seeds. These data suggest that survival of $P$. stewartii subsp. stewartii in watermelon seeds was enhanced by localization in embryo/endosperm tissues.

Overall, our data suggest that tolerance to desiccation does not explain A. citrulli's remarkable longevity in stored watermelon and melon seeds. Alternatively, it is likely that localization of the bacterium in embryo/endosperm tissues is important for long-term survival.

\section{ACKNOWLEDGMENTS}

We thank R. Christiano for assistance with statistical analysis and L. Genzlinger, I. Ontaneda, and A. Castro-Sparks for technical assistance.

\section{LITERATURE CITED}

Agarwal, V. K., and Sinclair, J. B. 1997. Longevity of seedborne pathogens. Pages 217-226 in: Principles of Seed Pathology. N. Levine and S. Kaplan, eds. CRC Press, New York.

Alvarez, B., López, M. M., and Biosca, E. G. 2008. Survival strategies and pathogenicity of Ralstonia solanacearum phylotype II subjected to prolonged starvation in environmental water microcosms. Microbiology 154:3590-3598.

Block, C. C., Hill, J. H., and McGee, D. C. 1998. Seed transmission of Pantoea stewartii in field and sweet corn. Plant Dis. 82:775-780.

Block, C. C., Hill, J. H., and McGee, D. C. 1999. Relationship between late season Stewart's bacterial wilt and seed infection in maize. Plant Dis. 83: 527-530.

Block, C. C., and Shepherd, L. M. 2008. Long-term survival and seed transmission of Acidovorax avenae subsp. citrulli in melon and watermelon seed. Online. Plant Health Progress. doi:10.1094/PHP-2008-1219-01-BR
Brumbley, S. M., and Denny, T. P. 1990. Cloning of phcA from wild-type Pseudomonas solanacearum, a gene that when mutated alters expression of multiple traits that contribute to virulence. J. Bacteriol. 172:5677-5685.

Burdman, S., Kots, N., Kritzman, G., and Kopelowitz, J. 2005. Molecular, physiological, and host-range characterization of Acidovorax avenae subsp. citrulli isolates from watermelon and melon in Israel. Plant Dis. 89:1339-1347.

Chen, Y., Zhang, W. Z., Liu, X., Ma, Z. H., Allen, C., and Guo, J. H. 2010. A real-time PCR assay for the quantitative detection of Ralstonia solanacearum in the horticultural soil and plant tissues. J. Microbiol. Biotechnol. 20:193-201.

Dutta, B., Avci, U., Hahn, M. G., and Walcott, R. R. 2012. Location of Acidovorax citrulli in infested watermelon seeds is influenced by the pathway of bacterial ingress. Phytopathology 102:461-468.

Dutta, B., Sanders, H., Langston, D. B., Booth, C., Smith, S., and Gitaitis, R. D. 2014. Long-term survival of Acidovorax citrulli in citron melon (Citrullus lanatus var. citroides) seeds. Plant Pathol. 63:1130-1137.

Fessehaie, A., Shepherd, L. M., Block, C. C., and Misra, K. M. 2006. A diagnostic real-time TaqMan PCR assay for the detection of Pantoea stewartii subsp. stewartii. (Abstr.) Phytopathology 96(suppl.):S35.

Ha, Y., Fessehaie, A., Ling, K. S., Wechter, W. P., Keinath, A. P., and Walcott, R. R. 2009. Simultaneous detection of Acidovorax avenae subsp. citrulli and Didymella bryoniae in cucurbit seedlots using magnetic capture hybridization and real-time polymerase chain reaction. Phytopathology 99:666-678.

Hopkins, D. L., Lovic, B., Hilgren, J., and Thompson, C. M. 2003. Wet seed treatment with peroxyacetic acid for the control of bacterial fruit blotch and other seedborne diseases of watermelon. Plant Dis. 87:1495-1499.

Hopkins, D. L., and Thompson, C. M. 2002. Seed transmission of Acidovorax avenae subsp. citrulli in cucurbits. HortScience 37:924-926.

King, E. O., Ward, M. K., and Raney, D. E. 1956. Two simple media for the demonstration of pyocyanin and fluorescin. J. Lab. Clin. Med. 44: 301-307.

Latin, R. X., and Hopkins, D. L. 1995. Bacterial fruit blotch of watermelon: The hypothetical exam question becomes reality. Plant Dis. 79:761-765.

Latin, R. X., and Rane, K. K. 1990. Bacterial fruit blotch of watermelon in Indiana. Plant Dis. 74:331.

Latin, R. X., Tikhonova, I., and Rane, K. 1995. Factors affecting the survival and spread of Acidovorax avenae subsp. citrulli in watermelon transplant production facilities. Phytopathology 85:1413-1417.

Leben, C. 1981. How plant-pathogenic bacteria survive. Plant Dis. 65:633-637.

Lessl, J. T., Fessehaie, A., and Walcott, R. R. 2007. Colonization of female watermelon blossoms by Acidovorax avenae subsp. citrulli and the relationship between blossom inoculum dosage and seed infestation. J. Phytopathol. 155:114-121.

Michener, P. M., Pataky, J. K., and White, D. G. 2002. Rates of transmitting Erwinia stewartii from seed to seedlings of a sweet corn hybrid susceptible to Stewart's wilt. Plant Dis. 86:1031-1035.

Milling, A., Meng, F., Denny, T. P., and Allen, C. 2009. Interactions with hosts at cool temperatures, not cold tolerance, explain the unique epidemiology of Ralstonia solanacearum race 3 biovar 2. Phytopathology 99:1127-1134.

Park, Y. J., Lee, B. M., Hahn, J. H., Lee, G. B., and Park, S. K. 2004. Sensitive and specific detection of Xanthomonas campestris pv. campestris by PCR using species-specific primers based on hrpF gene sequences. Microbiol. Res. 159:419-423.

Persley, G. J. 1979. Studies on the survival and transmission of Xanthomonas manihotis on cassava seed. Ann. Appl. Biol. 93:159-166.

Rane, K. K., and Latin, R. X. 1992. Bacterial fruit blotch of watermelon: Association of the pathogen with seed. Plant Dis. 76:509-512.

Schaad, N. W., Jones, J. B., and Chun, W. 2001. Laboratory Guide for Identification of Plant Pathogenic Bacteria, 3rd ed. The American Phytopathological Society, St. Paul, MN.

Schaad, N. W., Postnikova, E., and Randhawa, P. 2003. Emergence of Acidovorax avenae subsp. citrulli as a crop-threatening disease of watermelon and melon. Pages 573-581 in: Pseudomonas syringae and Related Pathogens: Biology and Genetics. N. A. Icobellis, A. Collmer, S. W. Hutcheson, J. W. Mansfield, C. E. Morrris, J. Murrillo, N. W. Schaad, D. E. Stead, G. E. Surico, and M. S. Ullrich, eds. Kluwer, Dordrecht, The Netherlands.

Schaad, N. W., Postnikova, E., Sechler, A., Claflin, L. E., Vidaver, A. K., Jones, J. B., Agakova, I., Ignatov, A., Dickstein, E., and Ramundo, B. A. 2008. Reclassification of subspecies of Acidovorax avenae as A. avenae (Manns 1905) emend., A. cattleyae (Pavarino, 1911) comb.nov., A. citrulli (Schaad et al., 1978) comb.nov., and proposal of A. oryzae sp. nov. Syst. Appl. Microbiol. 31: 434-446.

Schaad, N. W., Sowell, G., Goth, R. W., Colwell, R. R., and Webb, R. E. 1978. Pseudomonas pseudoalcaligenes subsp. citrulli subsp. nov. Int. J. Syst. Bacteriol. 28:117-125.

Schuster, M. L., and Coyne, D. P. 1974. Survival mechanisms of phytopathogenic bacteria. Annu. Rev. Phytopathol. 12:199-221. 
Somodi, G. C., Jones, J. B., Hopkins, D. L., Stall, R. E., Kucharek, T. A., Hodge, N. C., and Watterson, J. C. 1991. Occurrence of a bacterial watermelon fruit blotch in Florida. Plant Dis. 75:1053-1056.

Stephens, D. J., Schneider, R. W., Walcott, R. R., and Johnson, C. E. 2008. A procedure, based on exposure to chlorine gas, for disinfesting watermelon seeds. (Abstr.) Phytopathology 98(suppl.):S150.

Taylor, J. D., Dudley, C. L., and Presley, L. 1979. Studies of halo-blight seed infection and disease transmission. Ann. Appl. Biol. 93:267-277.

Walcott, R. R. 2008. Integrated pest management of bacterial fruit blotch in cucurbits. Pages 191-209 in: Integrated Management of Diseases Caused by Fungi, Phytoplasma and Bacteria. A. Ciancio and K. G. Mukherji, eds. Springer Science, New York.
Walcott, R. R. and Gitaitis, R. D. 2000. Detection of Acidovorax avenae subsp. citrulli in watermelon seed using immunomagnetic separation and the polymerase chain reaction. Plant Dis. 84:470-474.

Walcott, R. R., Gitaitis, R. D., and Castro, A. C. 2003. Role of blossoms in watermelon seed infestation by Acidovorax avenae subsp. citrulli. Phytopathology 93:528-534.

Willems, A., Goor, M., Thielemans, S., Gillis, M., Kersters, K., and Deley, J. 1992. Transfer of several phytopathogenic Pseudomonas species to Acidovorax as Acidovorax avenae subsp. avenae subsp. nov., comb., Acidovorax avenae subsp. citrulli, Acidovorax avenae subsp. cattlleyae, and Acidovorax avenae subsp. konjaci. Int. J. Syst. Bacteriol. 42: 107-119. 